Article

\title{
High-Performance Mg-Al-Bi Alloy Anode for Seawater Batteries and Related Mechanisms
}

\author{
Changqing Wu, Xu Meng and Wei Wang * \\ Department of Applied Chemistry, School of Chemical Engineering and Technology, Tianjin University, \\ Tianjin 300072, China; wcq1055023971@163.com (C.W.); mxmengxu@tju.edu.cn (X.M.) \\ * Correspondence: wangweipaper@tju.edu.cn
}

Received: 20 September 2020; Accepted: 26 October 2020; Published: 28 October 2020

\begin{abstract}
Bi}$, a group 15 element, was added to magnesium alloys and applied to seawater batteries in marine operating machinery to improve the electrochemical performance and corrosion resistance of the battery. The electrochemical properties of as-cast pure $\mathrm{Mg}, \mathrm{Mg}-8 \mathrm{Al}$, and $\mathrm{Mg}-8 \mathrm{Al}-\mathrm{xBi}$ alloy anodes in $3.5 \% \mathrm{NaCl}$ solution were researched. Electrochemical impedance spectroscopy and an immersion test in $3.5 \% \mathrm{NaCl}$ solution show that the $\mathrm{Mg}-8 \% \mathrm{Al}-0.4 \% \mathrm{Bi}$ alloy provides better corrosion resistance than $\mathrm{Mg}$ and the $\mathrm{Mg}-8 \mathrm{Al}$ alloy. The galvanostatic discharge results show that the $\mathrm{Mg}-8 \% \mathrm{Al}-0.4 \% \mathrm{Bi}$ alloy revealed better electrochemical properties and utilization efficiency in $3.5 \% \mathrm{NaCl}$ solution. The $\mathrm{Mg}_{17} \mathrm{Al}_{12}$ and $\mathrm{BiOCl}$ phases formed during the discharge process of the $\mathrm{Mg}-8 \% \mathrm{Al}-0.4 \% \mathrm{Bi}$ alloy play an important role in improving the electrochemical performance and utilization efficiency of the alloy.
\end{abstract}

Keywords: $\mathrm{Mg}-8 \mathrm{Al}-\mathrm{xBi}$ alloy; discharge; electrochemical performance; utilization efficiency

\section{Introduction}

Due to environmental pollution and energy issues, ocean research has attracted widespread attention and has become a hot topic; however, ocean research requires solutions to resolve its energy needs [1,2]. A seawater-activated battery was invented in the 1940s to solve the requirements of ocean exploration and research. This battery system applies active metal (e.g., magnesium, aluminum) as the battery anode; $\mathrm{AgCl}, \mathrm{CuCl}, \mathrm{Cu}_{2} \mathrm{I}_{2}$, and $\mathrm{PbCl}_{2}$ as the battery cathode; and natural seawater is used as the electrolyte, which is different from the lithium-ion battery system that normally uses porous carbon (e.g., graphite) as the anode [3] and metal oxide (e.g., LiMn2O4) as the cathode [4]. When the battery discharges, it uses seawater from the ocean as an electrolyte to enter the battery system [5-7]. The anode loses electrons and the anode metal continuously turns into metallic cations. At the cathode, metal chloride is reduced to metal and the battery forms a closed circuit [8]. Seawater-activated batteries can be used in a large number of marine operating equipment, such as ocean probes, submarines, ocean buoys, life jackets, and sonars [9-11]. As a new type of power source, seawater-activated batteries possess many strengths. Firstly, the electrolyte is seawater, so extra electrolytes and storage devices do not need to be found. For this reason, the weight of the appliance can be greatly reduced. Secondly, it is an open system, so the polarization phenomenon is avoided to a certain extent. With the continuous development of technology, seawater-dissolved oxygen batteries have begun to attract the attention of researchers in China and abroad [12]. In order to obtain high-performance seawater batteries, high-performance anode materials have become the focus of development [13].

The active metals used as chemical kinetic anodes are well known for their good performance. Magnesium is considered an ideal anode material for batteries due to its outstanding electrochemical properties. Firstly, magnesium has a negative standard electrode potential of $-2.363 \mathrm{~V}$ (SHE), which is more negative than other active metals such as aluminum, zinc, iron, and titanium [14-17]. Thus, 
a magnesium anode can theoretically demonstrate higher battery voltage. Secondly, magnesium has a relatively high capacity of $2.205 \mathrm{~A} \cdot \mathrm{h} / \mathrm{g}$. As a consequence, a magnesium anode can theoretically provide higher battery capacity [18,19]. Thirdly, magnesium has a low density of $1.74 \mathrm{~g} / \mathrm{cm}^{3}$, which can reduce the quality of the battery system. Fourthly, magnesium is rich in content and does not pollute the environment. Due to the above four advantages, magnesium is used as an excellent negative electrode material for seawater batteries [20,21].

Although magnesium is a good anode material for seawater batteries, there are still some problems to be solved. $\mathrm{A} \mathrm{Mg}(\mathrm{OH})_{2}$ film will form on the anode surface during the discharge process. This $\mathrm{Mg}(\mathrm{OH})_{2}$ film covers the electrode surface and impedes battery discharge, so the actual potential of the magnesium anode is more positive than its theoretical potential. In addition, the electrode efficiency of the magnesium anode cannot reach $100 \%$, owing to electrode self-discharge in the electrolyte. Finally, many metal particles fall off during the discharge process, and this part of magnesium cannot be used effectively, resulting in a reduction in active ingredients in the anode [22-25]. Now, magnesium alloy anode performance can be improved by alloying, heat treatment, hot extrusion [26], and electrolyte modification. Alloying is a simple and effective method [27-30]. According to reports, aluminum and zinc is added to magnesium to obtain better performance at the beginning. An AZ magnesium alloy has good corrosion resistance in $\mathrm{NaCl}$ solution but low discharge activity. Balasubramanian et al. [31] reported the performance of AZ31 magnesium alloy as a seawater battery anode. The cell voltage was close to $1.5 \mathrm{~V}$ for $400 \mathrm{~mA}$ at $30{ }^{\circ} \mathrm{C}$. Jingling Ma et al. [32] studied the effect of $\mathrm{Al}$ content on properties of an AZ magnesium alloy. The AZ91 magnesium alloy has the best electrochemical performance of $-1.193 \mathrm{~V}$ (vs. SHE) anode potential and 46\% utilization at $20 \mathrm{~mA} \mathrm{~cm}^{-2}$. Wang et al. [33] researched the reaction mechanism of an AP magnesium alloy in $3.5 \% \mathrm{NaCl}$ solution and found that the AP65 magnesium alloy has the best electrochemical performance of $-1.686 \mathrm{~V}$ (vs. SHE) anode potential and $84 \%$ utilization at $180 \mathrm{~mA} \mathrm{~cm}^{-2}$. Yuasa et al. [26] reported that Ca can improve the capability of a Mg-Al-Mn alloy and thins discharge products. The Mg-6Al-0.3Mn-2Ca alloy's anode potential increase by $0.088 \mathrm{~V}$ and its utilization rate increases by $10.6 \%$ compared to the $\mathrm{Mg}-6 \mathrm{Al}-0.3 \mathrm{Mn}$ anode at $10 \mathrm{~mA} \mathrm{~cm}^{-2}$. Feng et al. [34-36] reported that the $\mathrm{Mg}-\mathrm{Hg}-\mathrm{Ga}$ alloy can form $\mathrm{Mg} 21 \mathrm{Ga} 5 \mathrm{Hg} 3$ phases, which reduces the electron transfer resistance during discharge process. In addition, it reduces $\mathrm{Hg}$ pollution and $\mathrm{Mg}-1.6 \mathrm{Hg}-2 \mathrm{Ga}$ has good electrochemical performance of $-1.897 \mathrm{~V}$ (vs. SHE) anode potential and $74 \%$ utilization at $180 \mathrm{~mA} \mathrm{~cm}^{-2}$. In order to obtain anodes with higher utilization efficiency, more negative discharge potential, and no pollution to the environment, a new composition magnesium alloy needs to be developed.

It has been reported that the self-corrosion rate of a magnesium alloy is reduced after adding group 14 and 15 elements [37]. In addition to this, aluminum plays an important role in inhibiting self-discharge and improving electrode utilization. Therefore, in order to obtain a high-performance seawater battery anode, this study prepared a $\mathrm{Mg}-\mathrm{Al}-\mathrm{Bi}$ ternary alloy. In order to understand the effect of elements $\mathrm{Bi}$ and $\mathrm{Al}$ in the magnesium alloy discharge process, a series of $\mathrm{Mg}-\mathrm{Al}-\mathrm{Bi}$ alloys were prepared by a high frequency induction furnace. The open circuit potential-time curves, galvanostatic discharging curves, and electrochemical impedance spectra curves were measured to display the impact on electrode performance of element $\mathrm{Al}$ and $\mathrm{Bi}$. X-ray diffraction and scanning electron microscopy were used to analyze the changes in the structure and morphology of $\mathrm{Mg}-\mathrm{Al}-\mathrm{Bi}$ alloys in the galvanostatic discharging process. Based on the experimental data, a reaction mechanism is proposed to explain all the experimental phenomenon.

\section{Materials and Methods}

\subsection{Preparation of Materials}

A certain amount of commercial grade metal $\mathrm{Mg}$ (99.99\%), metal Al (99.99\%), and metal Bi (99.99\%) were prepared to smelt the $\mathrm{Mg}-\mathrm{Al}-\mathrm{Bi}$ alloy. The addition amounts of $\mathrm{Al}$ and $\mathrm{Bi}$ are shown in Table 1. The investigated metals were melted in a graphite crucible in a high frequency induction 
furnace. The pressure in the induction furnace was $-0.1 \mathrm{MPa}$ at the beginning by vacuumizing and subsequently, the pressure recovered to $0.3 \mathrm{MPa}$ by accessing argon. Then, the furnace started to heat at a stable heating power at $30 \%$ total power to $750{ }^{\circ} \mathrm{C}$. This process lasted $3 \mathrm{~min}$ and stayed for $7 \mathrm{~min}$ at $750{ }^{\circ} \mathrm{C}$, thus the uneven distribution of alloying elements reduced [38]. Finally, the molten alloys were poured into a preheated steel mold that was installed in the induction furnace and cooled down to $400{ }^{\circ} \mathrm{C}$ to remove from the induction furnace. The entire magnesium alloy preparation process is shown in Figure 1.

Table 1. Sample content of Mg-Al-Bi alloys.

\begin{tabular}{cccc}
\hline Sample & $\mathbf{B i}$ & $\mathbf{A l}$ & $\mathbf{M g}$ \\
\hline 1 & $0 \%$ & $0 \%$ & $100 \%$ \\
2 & $0 \%$ & $8 \%$ & $92.0 \%$ \\
3 & $0.2 \%$ & $8 \%$ & $91.8 \%$ \\
4 & $0.4 \%$ & $8 \%$ & $91.6 \%$ \\
5 & $0.6 \%$ & $8 \%$ & $91.4 \%$ \\
6 & $0.8 \%$ & $8 \%$ & $91.2 \%$ \\
7 & $1.0 \%$ & $8 \%$ & $91.0 \%$ \\
\hline
\end{tabular}

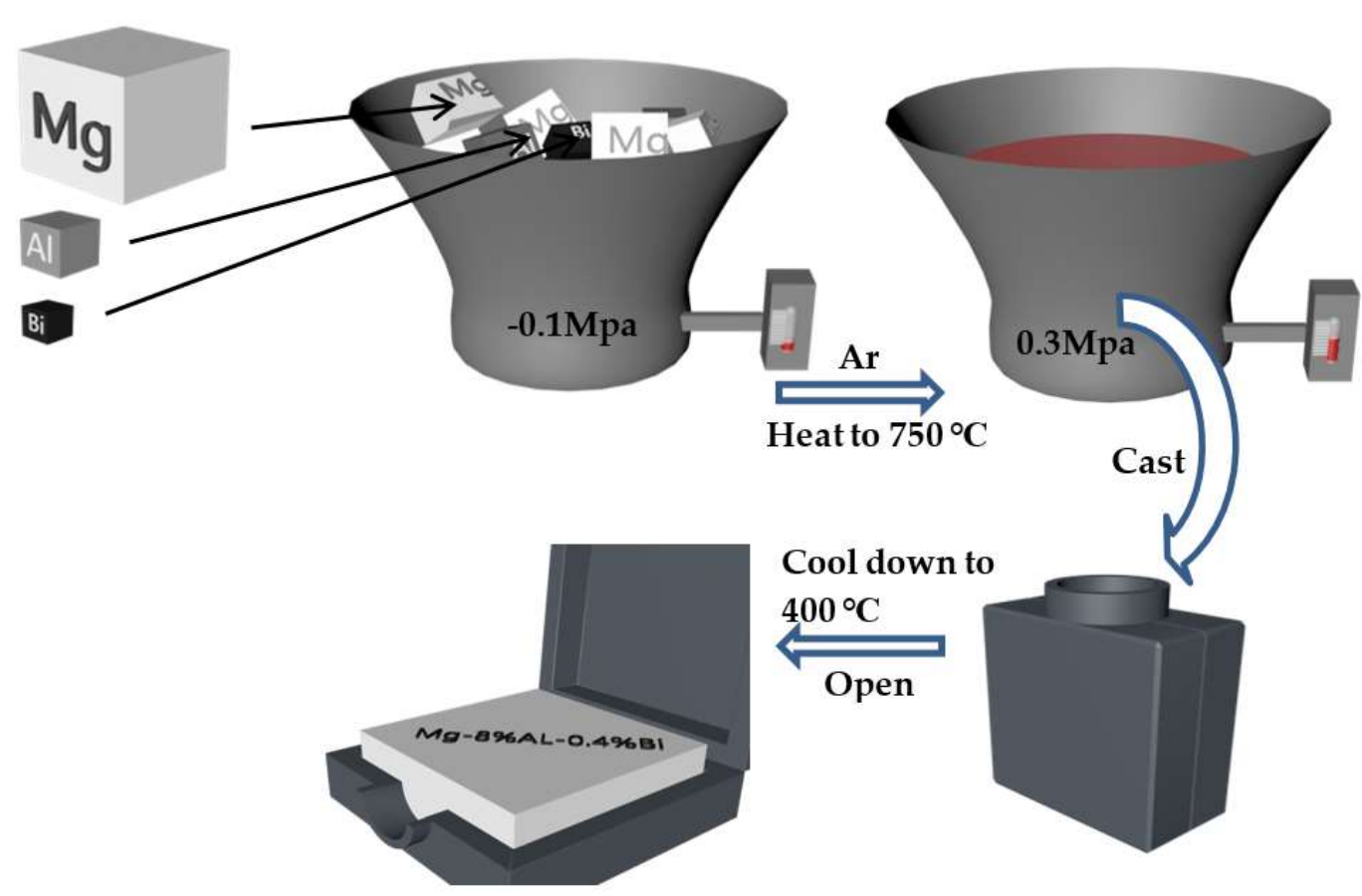

Figure 1. $\mathrm{Mg}-8 \% \mathrm{Al}-0.4 \mathrm{Bi}$ alloy preparation process

\subsection{Electrochemical Measurements}

A CHI660D electrochemical workstation was adopted to measure the electrochemical performance of the magnesium alloy anode. The electrochemical measurements were carried out at $25 \pm 1{ }^{\circ} \mathrm{C}$ by a three-electrode system. Ruthenium titanium mesh and saturated calomel electrode (SCE) were used as the counter electrode and reference electrode, respectively. The electrolyte was composed of $3.5 \mathrm{wt} \% \mathrm{NaCl}$ aqueous solution $(250 \mathrm{~mL}$ for each test). The magnesium alloy anode with an area of $1 \mathrm{~cm}^{2}$ sealed glue was ground with 240, 400, 1000, and 2000 mesh abrasive paper. Electrochemical impedance spectroscopy (EIS) measurements were conducted in the open circuit potential $+20 \mathrm{mV}$ and the measuring frequency was $0.1 \mathrm{~Hz}$ to $100 \mathrm{k} \mathrm{Hz}$. Galvanostatic discharging tests were tested at 
current densities 30 and $120 \mathrm{~mA} / \mathrm{cm}^{2}$, respectively. The anode utilization efficiency was acquired by calculating the theoretical weight loss and the actual weight loss in Equation (1).

$$
\text { Utilization efficiency }=\frac{W_{\text {theoretical }}}{W_{\text {actual }}} \times 100 \%
$$

\subsection{Structural Characterization}

The X-ray diffraction patterns of the Mg-Al-Bi alloys and pure Mg were recorded with a Rigaku MiniFlex II X-ray diffractometer. The $2 \theta$ angle regions between $20^{\circ}$ and $80^{\circ}$ were measured at a scan rate of $4^{\circ} \mathrm{min}^{-1}$. The grain size and lattice constant of $\mathrm{Mg}$ alloys were analyzed by JADE 6.5.

The scanning electron microscopy (SEM) observations were performed with a field-emission Hitachi s-4800 and SEM/energy dispersive spectrometer (EDS) spectroscopy mappings were undertaken at an acceleration voltage of $15 \mathrm{kV}$. X-ray photoelectron spectroscopy (XPS) was performed using a PHI5000 Versa Probe to analyze the chemical composition and valence state. The energy calibration of the spectrometer was performed using C 1 s peak at $284.5 \mathrm{eV}$.

\section{Results}

\subsection{Open Circuit Potential Analyses}

Figure 2 shows the open circuit potential-time curves of $\mathrm{Mg}-8 \% \mathrm{Al}-\mathrm{xBi}$ alloys measured at $25 \pm 1{ }^{\circ} \mathrm{C}$. The open circuit potential gradually became stable after testing for $400 \mathrm{~s}$. The relatively stable open circuit potential indicates that the electrochemical state on the electrode surface is relatively stable. The addition of $\mathrm{Bi}$ makes the open circuit potential of $\mathrm{Mg}-8 \% \mathrm{Al}-\mathrm{xBi}$ alloys negative from Bi content $0.2 \%$ to $0.4 \%$ and makes the open circuit potential positive from Bi content $0.6 \%$ to $1.0 \%$. The $\mathrm{Mg}-8 \% \mathrm{Al}-\mathrm{xBi}$ alloys with Bi content of $0.4 \%$ have the most negative open circuit potential, so they have the possibility of generating a more negative potential during galvanostatic discharging.
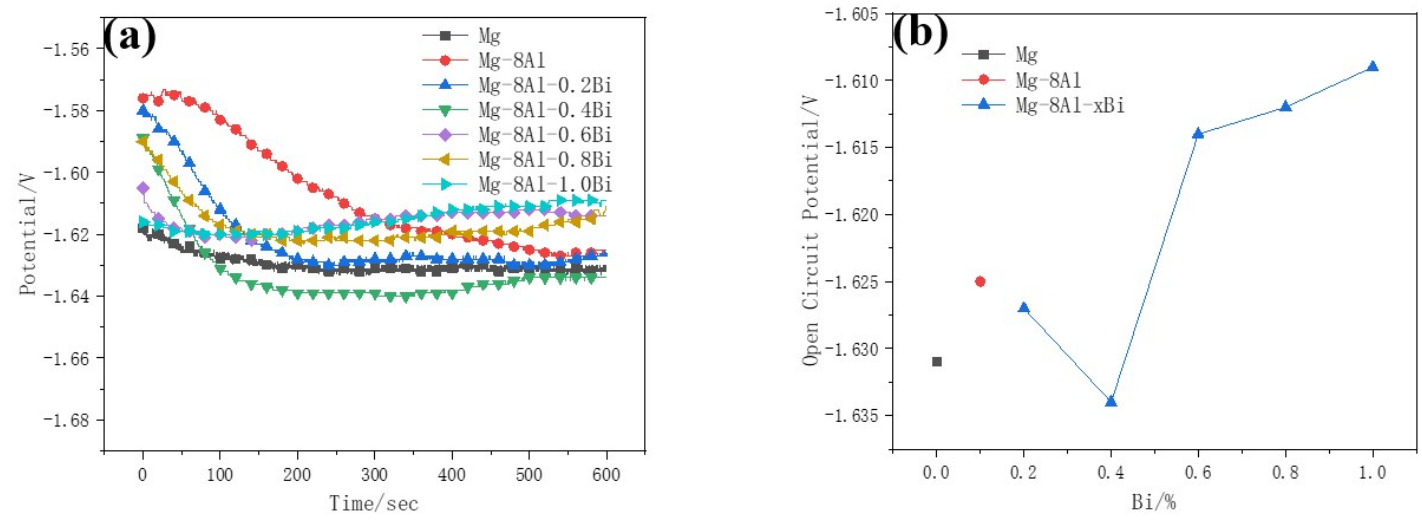

Figure 2. (a) Open circuit potential-time curves of $\mathrm{Mg}-8 \% \mathrm{Al}-\mathrm{xBi}$ alloys; (b) Open circuit potential-Bi content curves measured in $3.5 \% \mathrm{NaCl}$ solution.

\subsection{Galvanostatic Discharging Analyses}

Figure 3 displays the discharge curves and utilization efficiency-Bi content curves of $\mathrm{Mg}-8 \% \mathrm{Al}-\mathrm{xBi}$ alloys at 30 and $120 \mathrm{~mA} / \mathrm{cm}^{2}$. The tests of $\mathrm{Mg}-8 \% \mathrm{Al}-\mathrm{xBi}$ alloys under different Bi content were investigated. The $\mathrm{Mg}-8 \% \mathrm{Al}-\mathrm{xBi}$ anodes have more negative potential than the $\mathrm{Mg}$ anode and $\mathrm{Mg}-8 \% \mathrm{Al}$ anode. The $\mathrm{Mg}-\mathrm{Al}-\mathrm{Bi}$ anodes have relatively stable potential at 30 and $120 \mathrm{~mA} \mathrm{~cm}^{-2}$, but the $\mathrm{Mg}$ anode has serious polarization at $120 \mathrm{~mA} \mathrm{~cm}^{-2}$ and therefore, reduces its discharge performance. The potentials of $\mathrm{Mg}-8 \% \mathrm{Al}-\mathrm{xBi}, \mathrm{Mg}$, and $\mathrm{Mg}-8 \% \mathrm{Al}$ alloys all shift positively at the beginning of the galvanostatic discharging, then shift negative fast over different periods, and then, continue to move positively. This process is due to the discharge products attached to the electrode surface, which blocks 
the discharge process. The consequent sudden change in potential indicates the cracking of the passivation film. Finally, a dynamic balance is established between the formation and desorption of discharge products. By comparing Figure $3 a, b$, the potential change during the steady discharge period becomes obvious as the discharge current increases. This is caused by the accelerated corrosion rate of the electrode and the shedding of $\alpha-\mathrm{Mg}$ crystal grains. In general, the $\mathrm{Mg}-8 \% \mathrm{Al}-0.2 \% \mathrm{Bi}$ alloy has the most negative potential of $-1.466 \mathrm{~V}$ and the highest utilization efficiency of $56.6 \%$ when it is discharged at the current density of $30 \mathrm{~mA} / \mathrm{cm}^{2}$; the $\mathrm{Mg}-8 \% \mathrm{Al}-0.4 \% \mathrm{Bi}$ alloy has the most negative potential of $-1.185 \mathrm{~V}$ and the highest utilization efficiency of $72.4 \%$ when it is discharged at the current density of $120 \mathrm{~mA} / \mathrm{cm}^{2}$. By comparing $\mathrm{Mg}$, the $\mathrm{Mg}-8 \% \mathrm{Al}$ alloy, and the $\mathrm{Mg}-8 \% \mathrm{Al}-\mathrm{xBi}$ alloy, the potential of the $\mathrm{Mg}-8 \% \mathrm{Al}-\mathrm{xBi}$ alloy is more negative than that of $\mathrm{Mg}$ or the $\mathrm{Mg}-8 \% \mathrm{Al}$ alloy and the utilization efficiency is higher. This effect is attributed to the intermetallic $\mathrm{Mg}_{17} \mathrm{Al}_{12}$ and Bi oxide, which can destroy the $\mathrm{Mg}(\mathrm{OH})_{2}$ film formed on the anode surface, making the electrolyte easy to contact with the matrix $[37,39,40]$. The $\mathrm{Mg}_{17} \mathrm{Al}_{12}$ phase is good for stripping of corrosion products, avoiding the polarization of the electrode. The addition of Bi makes the potential show a positive trend with the increase in Bi content at $30 \mathrm{~mA} / \mathrm{cm}^{2}$. In addition, the potential shows a negative trend with the increase in Bi content from $0 \%$ to $0.4 \%$ and then, shows a positive trend with the increase in Bi content from $0.4 \%$ to $1.0 \%$ at $120 \mathrm{~mA} / \mathrm{cm}^{2}$. The more negative the alloy discharge potential, the higher the utilization efficiency.
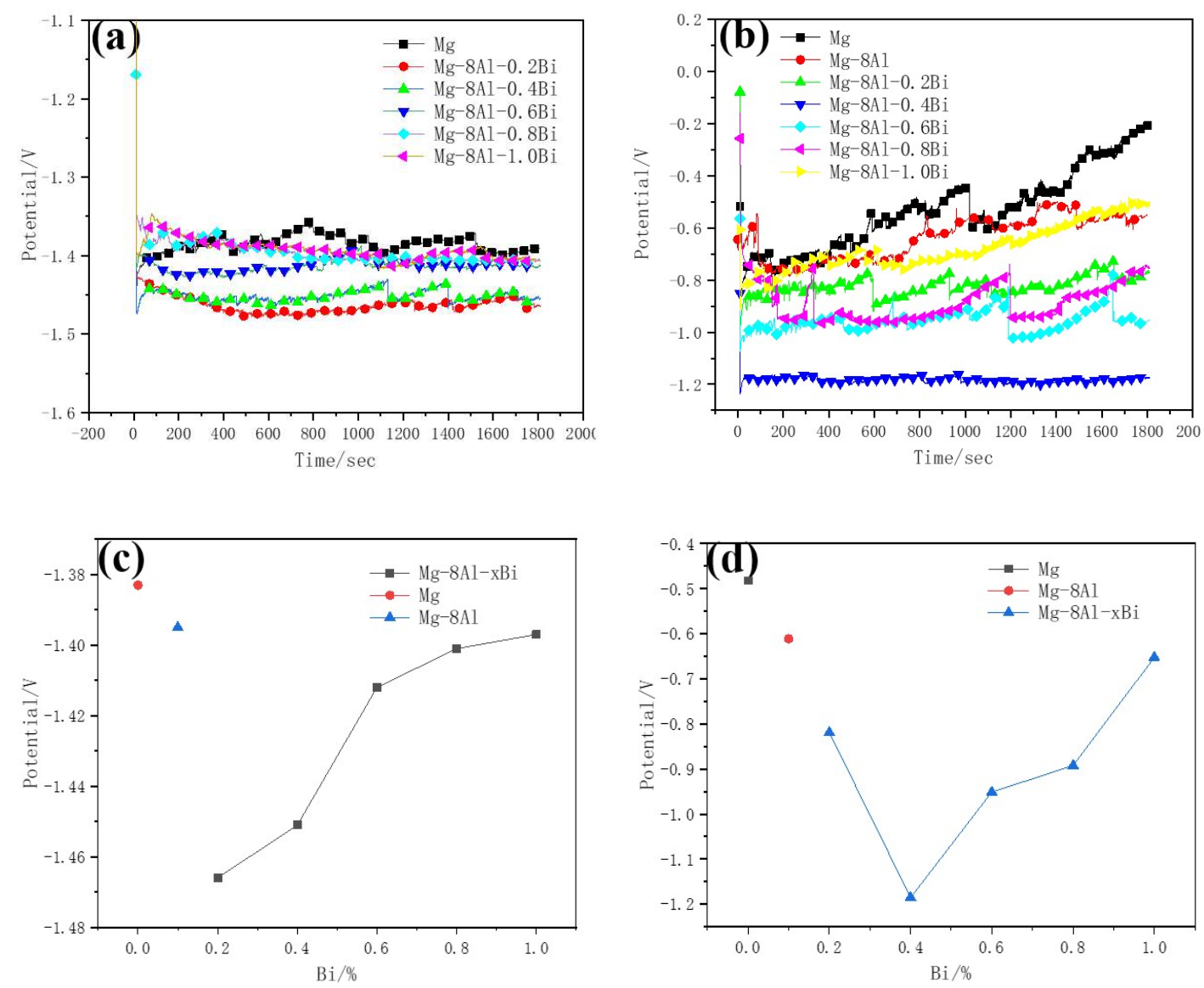

Figure 3. Cont. 

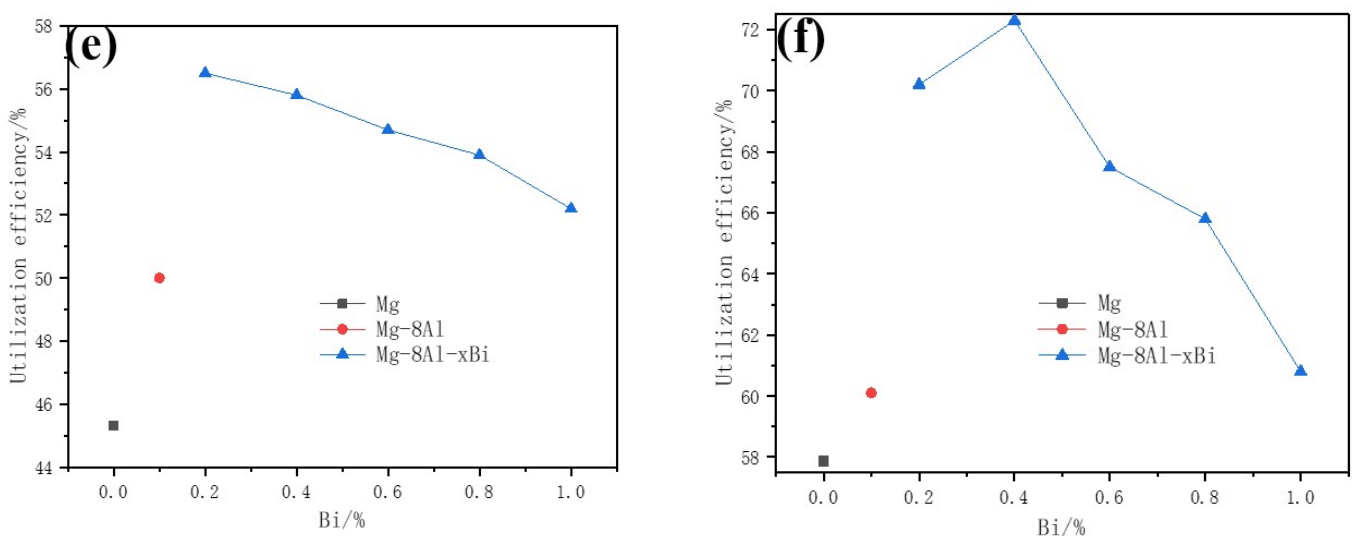

Figure 3. Discharge curves of $\mathrm{Mg}-8 \% \mathrm{Al}-\mathrm{xBi}$ electrode with different Bi content at (a) $30 \mathrm{~mA} / \mathrm{cm}^{2}$ and (b) $120 \mathrm{~mA} / \mathrm{cm}^{2}$; Discharge potential-Bi content curves at (c) $30 \mathrm{~mA} / \mathrm{cm}^{2}$ and (d) $120 \mathrm{~mA} / \mathrm{cm}^{2}$; Utilization efficiency-Bi content curves of Mg-Bi alloy at (e) $30 \mathrm{~mA} / \mathrm{cm}^{2}$ and (f) $120 \mathrm{~mA} / \mathrm{cm}^{2}$, measured in $3.5 \%$ $\mathrm{NaCl}$ solution.

\subsection{Microstructures}

Figure 4 shows the $\mathrm{XRD}$ patterns of the $\mathrm{Mg}-8 \% \mathrm{Al}$ and $\mathrm{Mg}-8 \% \mathrm{Al}-0.4 \% \mathrm{Bi}$ alloys and the $4 \mathrm{~N}$ grade $\mathrm{Mg}$. The peak positions of $\mathrm{Mg}$ are in accordance with the standard powder diffraction pattern of $\mathrm{Mg}$ (PDF\#35-0821), but the peak positions shifted after adding the Al element compared with the standard powder diffraction pattern of $\mathrm{Mg}$ (PDF\#35-0821). This is because the addition of a large amount of aluminum changes the lattice structure of magnesium and simultaneously forms the $\mathrm{Mg}_{17} \mathrm{Al}_{12}$ (PDF\#73-1148) phase. The grain sizes and lattice constants from the XRD data are calculated in Table 2. The lattice parameters of $\mathrm{Mg}-8 \% \mathrm{Al}-0.4 \% \mathrm{Bi}$ alloys increase with the addition of elements $\mathrm{Al}$ and $\mathrm{Bi}$. As shown in Table 2, the lattice parameters of pure magnesium change when alloying elements are added. The grain size is arranged in the following order: $\mathrm{Mg}-8 \% \mathrm{Al}-0.4 \% \mathrm{Bi}<\mathrm{Mg}-8 \% \mathrm{Al}<\mathrm{Mg}$, denoting the addition of $\mathrm{Al}$ and $\mathrm{Bi}$ is beneficial to reduce the grain size of $\mathrm{Mg}$ alloys. In the $\mathrm{Mg}-8 \% \mathrm{Al}-0.4 \% \mathrm{Bi}$ XRD pattern, the Bi element content is too low and therefore, cannot be reflected.

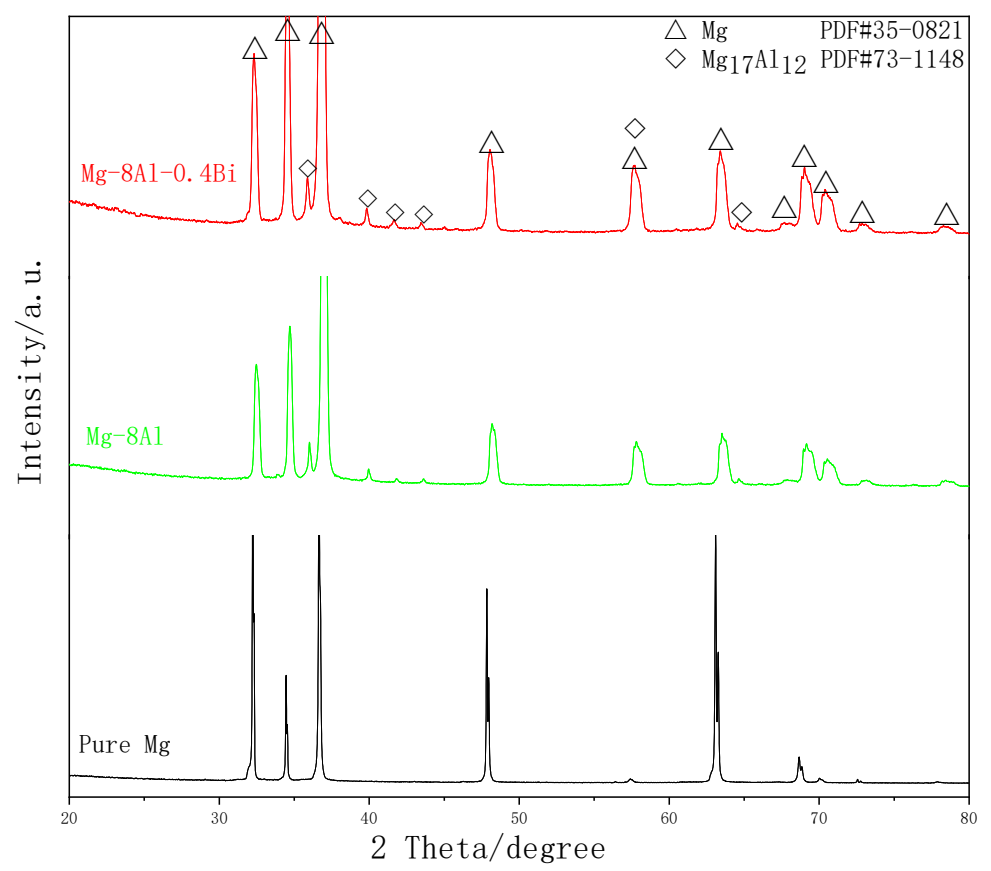

Figure 4. XRD patterns of pure $\mathrm{Mg}, \mathrm{Mg}-8 \% \mathrm{Al}$, and $\mathrm{Mg}-8 \% \mathrm{Al}-0.4 \% \mathrm{Bi}$ alloy. 
Table 2. Grain size and lattice parameters of the $\mathrm{Mg}-\mathrm{Al}-\mathrm{Bi}$ alloys.

\begin{tabular}{|c|c|c|c|c|}
\hline \multirow{2}{*}{ Sample } & \multirow{2}{*}{ Grain Size/Å } & \multicolumn{3}{|c|}{ Lattice Parameters/Å } \\
\hline & & $\mathbf{a}$ & $\mathbf{b}$ & c \\
\hline $\mathrm{Mg}$ & 753 & 3.2294 & 3.2294 & 5.1599 \\
\hline $\mathrm{Mg}-8 \% \mathrm{Al}$ & 251 & 3.1825 & 3.1825 & 5.3346 \\
\hline $\mathrm{Mg}-8 \% \mathrm{Al}-0.4 \% \mathrm{Bi}$ & 244 & 3.1971 & 3.1971 & 5.3540 \\
\hline
\end{tabular}

\subsection{XPS Analyses}

In order to further determine the chemical composition of the Bi element in the discharge product, XPS was used to prove the existence of the low-content element and to detect its valence. Figure 5 is the peak fitting curve of the XPS spectrum of Bi4f for $\mathrm{Mg}-8 \% \mathrm{Al}-0.4 \% \mathrm{Bi}$ alloy discharging for $30 \mathrm{~min}$ at $120 \mathrm{~mA} \mathrm{~cm}^{-2}$. It reveals that the XPS spectrum of Bi4f has two high peaks and two low peaks. By fitting data and comparing with standard binding energy, the peak of $B i 4 f_{5 / 2}$ has a peak of Bi with a binding energy of $157 \mathrm{eV}$ and a characteristic peak of $\mathrm{Bi}^{3+}$ with a binding energy of $159 \mathrm{eV}$. Due to the presence of chloride ions and the neutral $\mathrm{pH}$ of the solution, $\mathrm{Bi}^{3+}$ exists in the form of $\mathrm{BiOCl}$ [41].

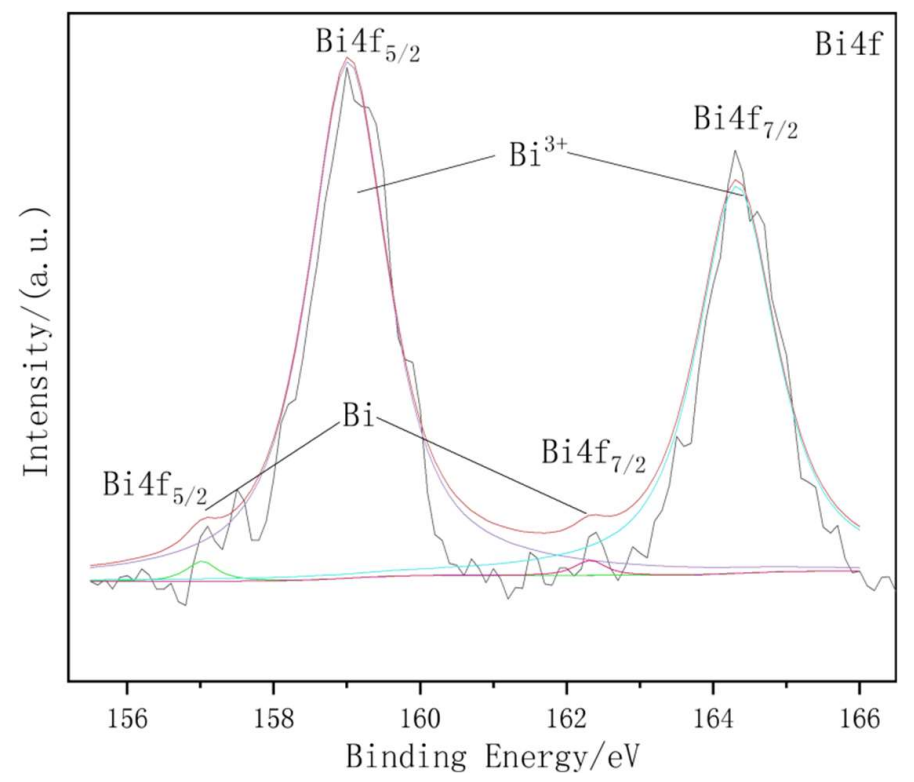

Figure 5. XPS spectrum of Bi4f for Mg-8\%Al-0.4\%Bi alloy discharged at $120 \mathrm{~mA} / \mathrm{cm}^{2}$ for $30 \mathrm{~min}$.

\subsection{SEM and EDS Analyses}

Figure $6 \mathrm{a}, \mathrm{b}$ show the SEM image of $\mathrm{Mg}$ anode and $\mathrm{Mg}-8 \% \mathrm{Al}-0.4 \% \mathrm{Bi}$ anode surfaces after discharge at $120 \mathrm{~mA} / \mathrm{cm}^{2}$ for $30 \mathrm{~min}$. It is observed that the discharge products are distributed on the anode surface in $\mathrm{Mg}$ and $\mathrm{Mg}-8 \% \mathrm{Al}-0.4 \% \mathrm{Bi}$ anodes The discharge product of $\mathrm{Mg}$ anode is thicker and has fewer surface cracks, while the discharge product of $\mathrm{Mg}-8 \% \mathrm{Al}-0.4 \% \mathrm{Bi}$ anode is thinner and has more surface cracks. According to reports, the discharge performance of $\mathrm{Mg}$ batteries is related to their appearance during discharge. Cao et al. [42] proved that the discharge products attached to the surface of the $\mathrm{Mg}-\mathrm{Li}-\mathrm{Al}-\mathrm{Ce}-\mathrm{Zn}-\mathrm{Mn}$ alloy are loose small pieces. These loose oxidation products allow the electrolyte to penetrate and maintain the anode discharge activity, while the bulk discharge products quickly fall off. Therefore, the cracks that appear on the discharge product shown in Figure 5 will also promote the penetration of the electrolyte into the discharge product and maintain contact with the substrate to maintain its discharge activity, while the thick one with fewer cracks formed on the surface of the magnesium anode blocks the contact between the electrolyte and the anode surface. Therefore, $\mathrm{Mg}-8 \% \mathrm{Al}-0.4 \% \mathrm{Bi}$ shows better discharge performance. 

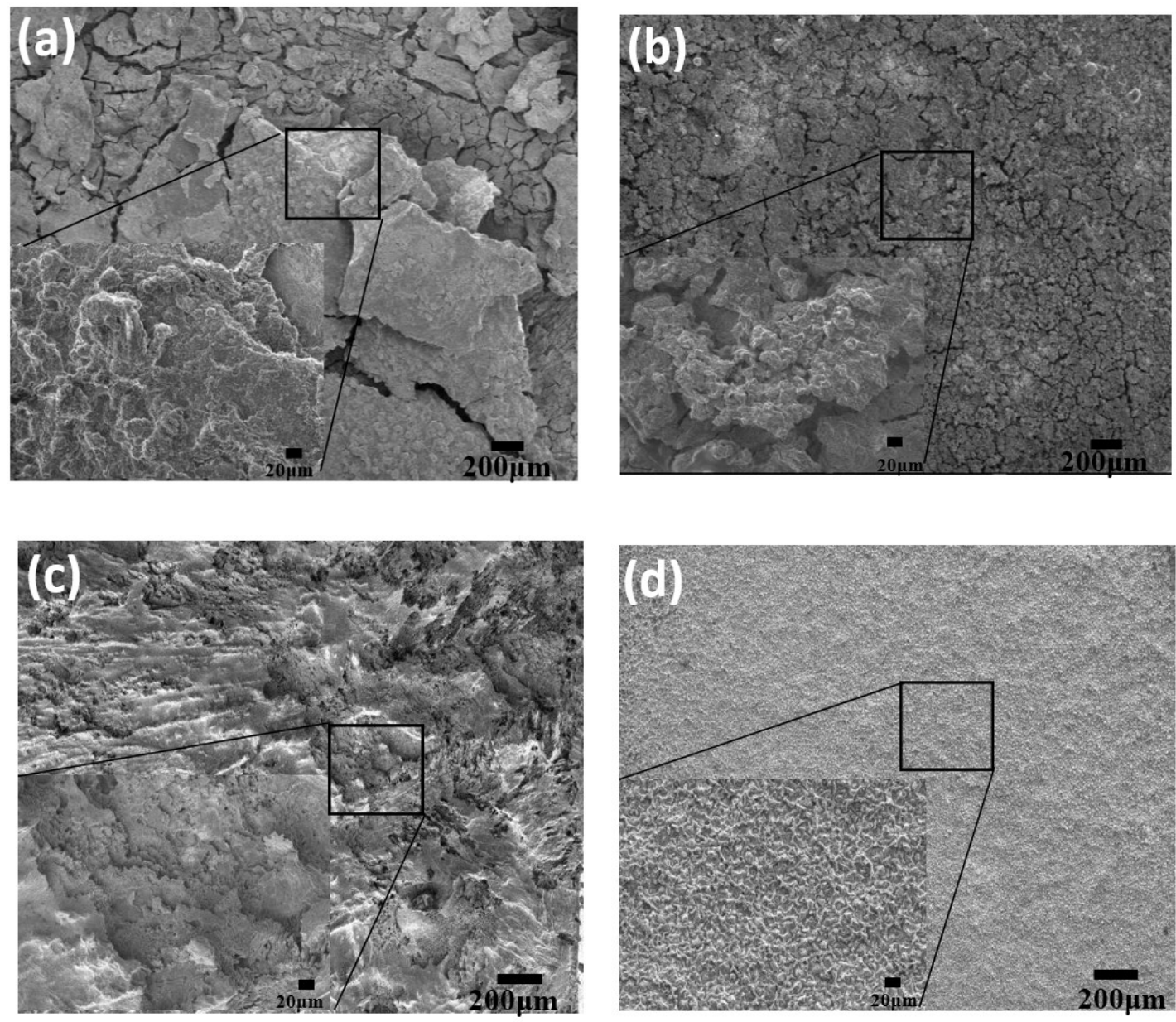

Figure 6. SEM images of (a) $\mathrm{Mg}$ and (b) $\mathrm{Mg}-8 \% \mathrm{Al}-0.4 \% \mathrm{Bi}$ discharged at $120 \mathrm{~mA} / \mathrm{cm}^{2}$ for 20 min with discharge products; (c) $\mathrm{Mg}$ and (d) $\mathrm{Mg}-8 \% \mathrm{Al}-0.4 \% \mathrm{Bi}$ discharged at $120 \mathrm{~mA} / \mathrm{cm}^{2}$ for $20 \mathrm{~min}$ without discharge products.

Figure $6 \mathrm{c}$, d show the SEM image of the $\mathrm{Mg}$ anode and $\mathrm{Mg}-8 \% \mathrm{Al}-0.4 \% \mathrm{Bi}$ anode surfaces discharged at $120 \mathrm{~mA} / \mathrm{cm}^{2}$ without discharge products. The $\mathrm{Mg}-8 \% \mathrm{Al}-0.4 \% \mathrm{Bi}$ anode surface is uniformly dissolved. In contrast, larger corrosion pits were observed on the magnesium anode. The deep pits observed in the $\mathrm{Mg}$ anode may be caused by the shedding of $\alpha$-Mg grains from the anode during the discharge. These shed $\alpha-\mathrm{Mg}$ grains cannot be used for discharge, resulting in a decrease in discharge capacity and anode utilization efficiency [43,44]. As shown in Figure 6, the surface of the Mg-8\%Al-0.4\%Bi anode was uniformly corroded, and no corrosion pits were observed. This is considered to be another reason why the discharge performance and anode efficiency of the $\mathrm{Mg}-8 \% \mathrm{Al}-0.4 \% \mathrm{Bi}$ anode are higher than those of the $\mathrm{Mg}$ anode under high current density.

Figure 7a shows the SEM image of the $\mathrm{Mg}-8 \% \mathrm{Al}-0.4 \% \mathrm{Bi}$ alloy and the EDS results of magnesium and the alloying elements' distribution. According to Figure 7, most of the $\mathrm{Al}$ elements are evenly distributed on the surface, and the Bi element content is too low to be detected. No obvious second phase can be observed in the image. Figure $7 \mathrm{~b}$ shows the SEM image of the corroded surface morphology and the related EDS results of the $\mathrm{Mg}-8 \% \mathrm{Al}-0.4 \% \mathrm{Bi}$ alloy after discharge at the current densities of $120 \mathrm{mAcm}^{-2}$ for $30 \mathrm{~min}$ without discharge product. According to the EDS results in Figure $\mathrm{7b}, \mathrm{Al}$ elements gather together and basically exist in the form of $\mathrm{Mg}_{17} \mathrm{Al}_{12}$ phase, and at the same time, Bi elements are enriched on the anode surface after discharge in the form of $\mathrm{BiOCl}$. They formed a protective layer on the surface of the anode to reduce self-discharge and strip the thick $\mathrm{Mg}(\mathrm{OH})_{2}$ passivation film. Therefore, the discharge performance and utilization efficiency of the battery were improved. 

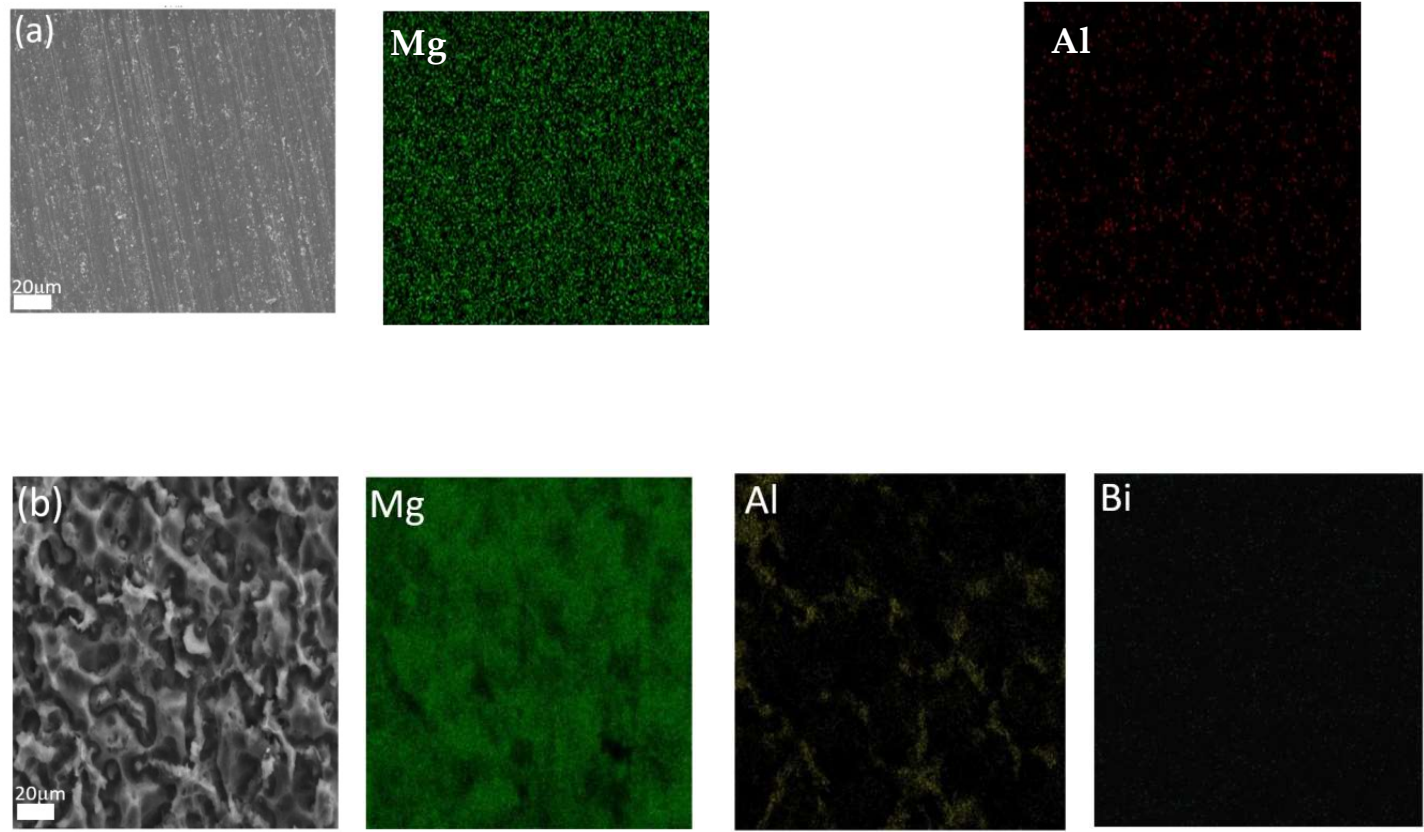

Figure 7. Element mapping of elements $\mathrm{Mg}, \mathrm{Al}$, and $\mathrm{Bi}$ for (a) as-cast $\mathrm{Mg}-8 \% \mathrm{Al}-0.4 \% \mathrm{Bi}$ and (b) $\mathrm{Mg}-8 \% \mathrm{Al}-0.4 \% \mathrm{Bi}$ alloy discharged at $120 \mathrm{~mA} / \mathrm{cm}^{2}$ for $30 \mathrm{~min}$ without discharge products.

\subsection{Electrochemical Impedance Spectroscopy (EIS) Analyses}

Figure 8 displays the Nyquist plots of $\mathrm{Mg}, \mathrm{Mg}-8 \% \mathrm{Al}$, and $\mathrm{Mg}-8 \% \mathrm{Al}-0.4 \% \mathrm{Bi}$ measured in $3.5 \% \mathrm{NaCl}$ solution at $25 \pm 1{ }^{\circ} \mathrm{C}$. According to Figure 8, the interfacial processes and corrosion mechanisms are studied. The shapes of the Nyquist diagrams of all three samples are similar, so they have similar electrochemical behavior. All Nyquist plots have three parts: two capacitive semicircles at high frequency and medium frequency, and one inductive semicircle at low frequency. The capacitive semicircles at high frequency and medium frequency are related to electron transfer and the electrochemical double-layer. The larger the radius of the semicircle, the greater the corrosion resistance. The radius of the loops increases according to the order $\mathrm{Mg}<\mathrm{Mg}-8 \% \mathrm{Al}<\mathrm{Mg}-8 \% \mathrm{Al}-0.4 \% \mathrm{Bi}$. There is a low frequency induction semicircle in almost all magnesium alloys, which may be attributed to the interaction of corrosion products and the corroded alloy surface. The Mg- $8 \% \mathrm{Al}-0.4 \% \mathrm{Bi}$ alloy possesses the highest impedance and it exhibits the optimal corrosion resistance, which is consistent with the results obtained in the immersion experiment. In order to explain the Nyquist plots, an equivalent circuit is used to model the impedance (Figure 8b). Table 3 lists the main EIS parameters of the equivalent circuit fitted by ZSimpWin software. In the equivalent circuit fitting parameters of the $\mathrm{Mg}$ alloy, $\mathrm{CPE}_{\mathrm{ct}}$ and $\mathrm{R}_{\mathrm{ct}}$ describe the electrochemical double layer and the charge transfer resistance, respectively; $\mathrm{CPE}_{\text {film }}$ and $\mathrm{R}_{\text {film }}$ describe the capacitance and resistance of the passivation film on the alloy, respectively. $R$ and $L$, respectively, describe the low frequency inductance resistance and inductance resulting from the adsorption of corrosion products. Rs describes the resistance of the solution. The value of $R_{c t}+R_{\text {film }}$ determines the corrosion resistance of the material in the electrolyte. The larger the value of $R_{c t}+R_{\text {film }}$, the better the corrosion resistance. The $R_{c t}+R_{f i l m}$ of $\mathrm{Mg}-8 \% \mathrm{Al}-0.4 \% \mathrm{Bi}$ alloy reaches $205 \Omega$, while the $\mathrm{R}_{\mathrm{ct}}+\mathrm{R}_{\mathrm{film}}$ of pure $\mathrm{Mg}$ is $19.941 \Omega$. For the $\mathrm{Mg}-8 \% \mathrm{Al}-0.4 \% \mathrm{Bi}$ alloy, the observed $\mathrm{R}_{\mathrm{ct}}+\mathrm{R}_{\mathrm{film}}$ is much larger than that of the $\mathrm{Mg}$ and $\mathrm{Mg}-8 \% \mathrm{Al}$ alloys. It shows the $\mathrm{Mg}-8 \% \mathrm{Al}-0.4 \% \mathrm{Bi}$ alloy has better corrosion resistance, which is consistent with the results of the immersion experiment. 

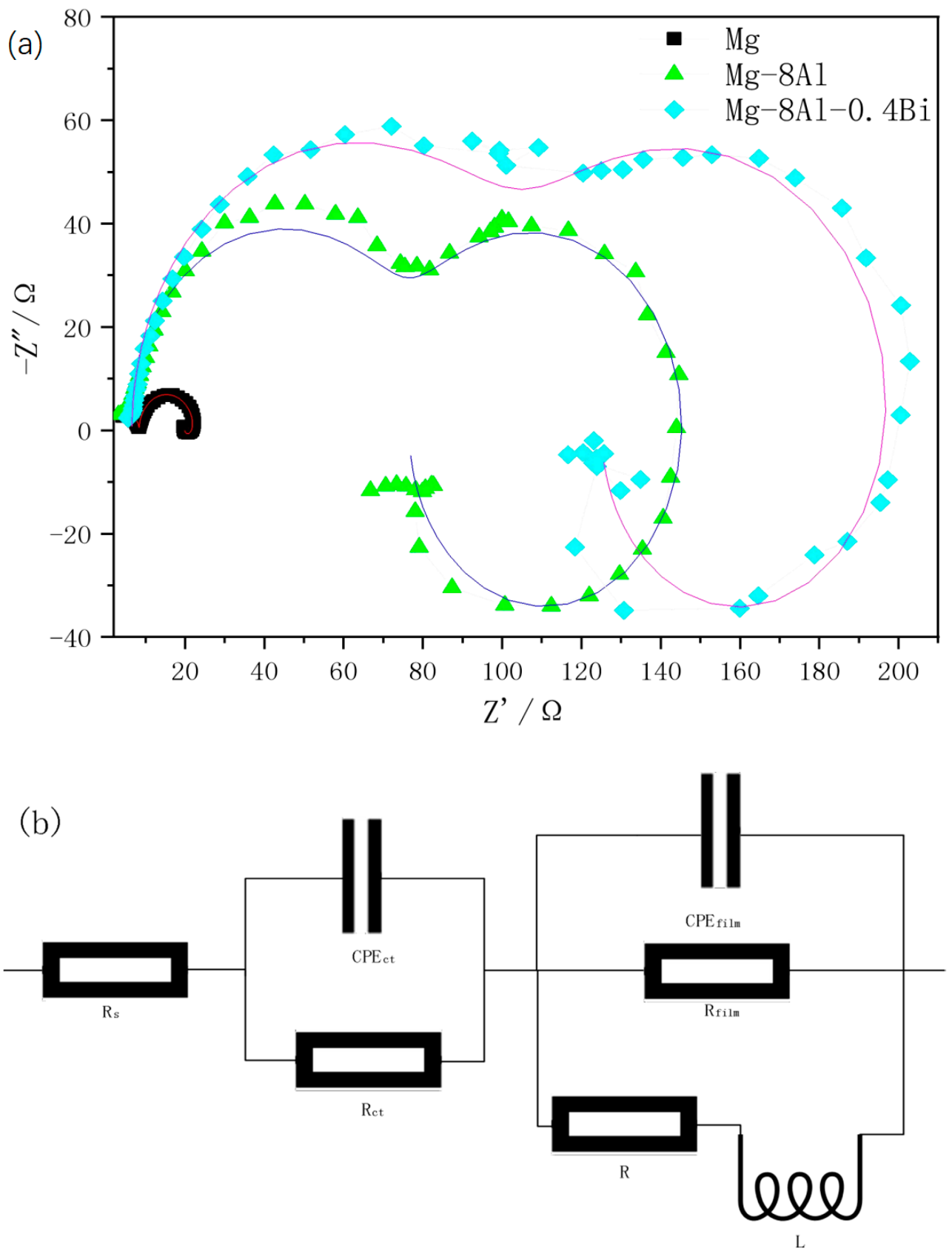

Figure 8. (a) Nyquist curves of Mg and Mg alloys. (b) Equivalent circuit diagram of Figure 7a measured in $3.5 \% \mathrm{NaCl}$ solution.

Table 3. Parameter values of the equivalent elements in Figure 7.

\begin{tabular}{cccccccc}
\hline Sample & $\mathbf{R s} / \boldsymbol{\Omega}$ & $\mathrm{CPE}_{\mathrm{ct}} / \boldsymbol{\mu F}$ & $\mathbf{R}_{\mathrm{ct}} / \mathbf{\Omega}$ & $\mathrm{CPE}_{\text {film }} / \mathbf{m F}$ & $\mathbf{R}_{\text {film }} / \boldsymbol{\Omega}$ & $\mathbf{L} / \mathbf{H}$ & $\mathbf{R} / \boldsymbol{\Omega}$ \\
\hline $\mathrm{Mg}$ & 3.008 & 0.4493 & 5.751 & 0.2322 & 14.19 & 0.6358 & 6.6100 \\
$\mathrm{Mg}-8 \mathrm{Al}$ & 5.662 & 5.676 & 70.92 & 0.1200 & 68.74 & 6.685 & 60.0641 \\
$\mathrm{Mg}-8 \mathrm{Al}-0.4 \mathrm{Bi}$ & 6.612 & 9.877 & 106.5 & 0.1120 & 98.50 & 10.1 & 74.8830 \\
\hline
\end{tabular}

\subsection{Immersion Test Analyses}

The corrosion rate curves of the $\mathrm{Mg}, \mathrm{Mg}-8 \% \mathrm{Al}$, and $\mathrm{Mg}-8 \% \mathrm{Al}-\mathrm{xBi}$ alloys were compared in Figure 9. It reflects that the $\mathrm{Mg}-8 \% \mathrm{Al}-0.4 \% \mathrm{Bi}$ alloy has the slowest corrosion rate and its chemical corrosion resistance is better than that of $\mathrm{Mg}$ and the $\mathrm{Mg}-8 \% \mathrm{Al}$ alloy. The corrosion rate of all alloys 
is faster at the beginning of corrosion, then gradually slows down, and finally, tends to be constant. Because a passivation film is formed on the surface of the alloy, the protection of the passivation film and the hydrogen evolution overpotential of the alloy determine the alloy's corrosion rate. The better protection of the passivation film, the higher the hydrogen evolution overpotential of the alloy, and the slower the corrosion rate. The results indicate that the addition of metal Bi slows down the evolution of hydrogen because $\mathrm{Bi}$ is a high hydrogen evolution overpotential metal. Therefore, the chemical corrosion rate of the $\mathrm{Mg}-\mathrm{Al}-\mathrm{Bi}$ alloy is lower than that of pure magnesium and pure aluminum [45].
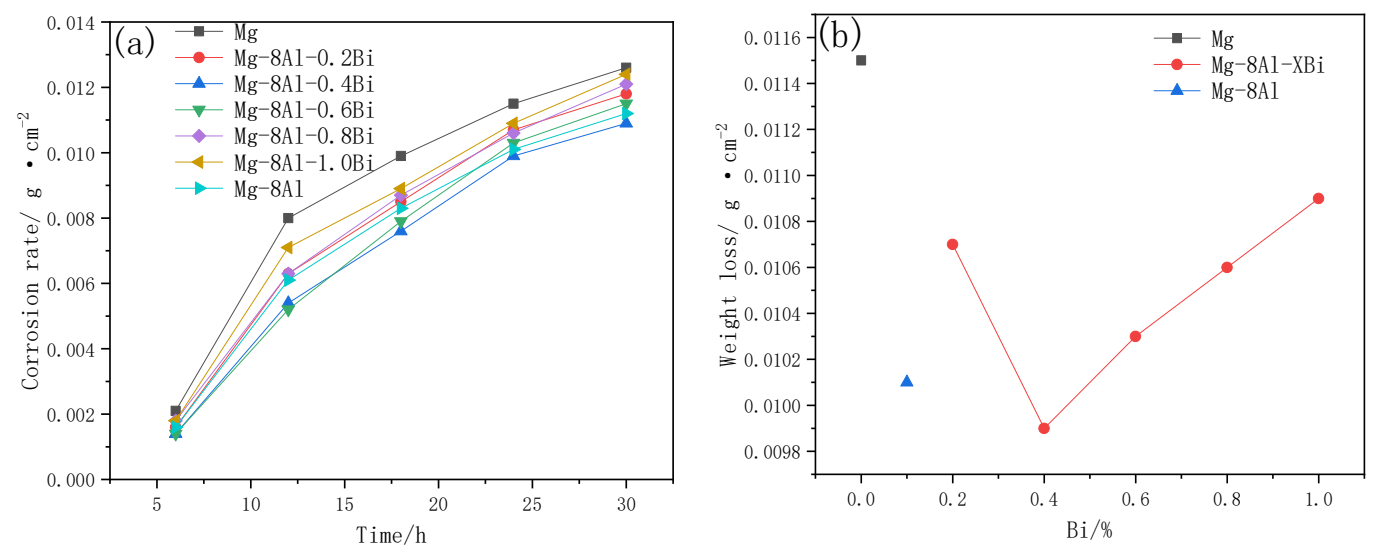

Figure 9. (a) Corrosion rate-time curves of $\mathrm{Mg}-8 \% \mathrm{Al}-\mathrm{xBi}$ alloys measured in $3.5 \% \mathrm{NaCl}$ solution. (b) Weight loss-Bi content of $\mathrm{Mg}-8 \% \mathrm{Al}-\mathrm{xBi}$ alloys soaked in $3.5 \% \mathrm{NaCl}$ solution for $24 \mathrm{~h}$.

The anode surface morphologies of pure $\mathrm{Mg}$ and $\mathrm{Mg}$ alloys immersed in $3.5 \mathrm{wt} \% \mathrm{NaCl}$ solution for 12 and $24 \mathrm{~h}$ are shown in Figure 10. According to the microstructure and corrosion morphology, corrosion can be classified as either "dotted" or "flaky" corrosion type. The degree of corrosion at the center of the sample is determined by the alloy properties, while the corrosion at the edge of the sample is determined by the alloy properties and edge stress. The corrosion morphology of the $\mathrm{Mg}-8 \% \mathrm{Al}$ alloy is similar to that of the $\mathrm{Mg}-8 \% \mathrm{Al}-0.4 \% \mathrm{Bi}$ alloy, which is mainly flaky. The metallographic photograph indicates that corrosion started to form small flaky corrosion areas and then, connected into a larger corrosion areas. The formation of larger "flaky" corrosion areas and deep pitting corrosion of pure $\mathrm{Mg}$ revealed that the occurrence and spread of corrosion was very fast. That is, pure magnesium can quickly initiate corrosion, but cannot prevent the spread of corrosion. The corrosion products exist in the form of individual large pieces and are not connected into flakes. This leads to a lower corrosion resistance of pure magnesium. The degree of corrosion increases in the order $\mathrm{Mg}-8 \% \mathrm{Al}-0.4 \% \mathrm{Bi}<$ $\mathrm{Mg}-8 \% \mathrm{Al}<\mathrm{Mg}$. Hence, the $\mathrm{Mg}-8 \% \mathrm{Al}-0.4 \% \mathrm{Bi}$ alloy shows the best corrosion resistance, and the pure Mg exhibits the most serious corrosion. In Figure 10, the edge corrosion of pure magnesium is light, but the center corrosion is serious. It has good edge stress resistance, but the matrix has poor resistance to chemical corrosion. The pitting corrosion of pure magnesium spreads to the depths of the magnesium matrix, causing more serious corrosion. The corrosion of $\mathrm{Mg}-8 \% \mathrm{Al}$ alloy and $\mathrm{Mg}-8 \% \mathrm{Al}-0.4 \% \mathrm{Bi}$ alloy is basically concentrated on the edge, and the corrosion resistance of the matrix is better. $\mathrm{Mg}-8 \% \mathrm{Al}-0.4 \% \mathrm{Bi}$ has the least degree of corrosion, so its corrosion resistance is the strongest in $3.5 \% \mathrm{NaCl}$ without discharge. 

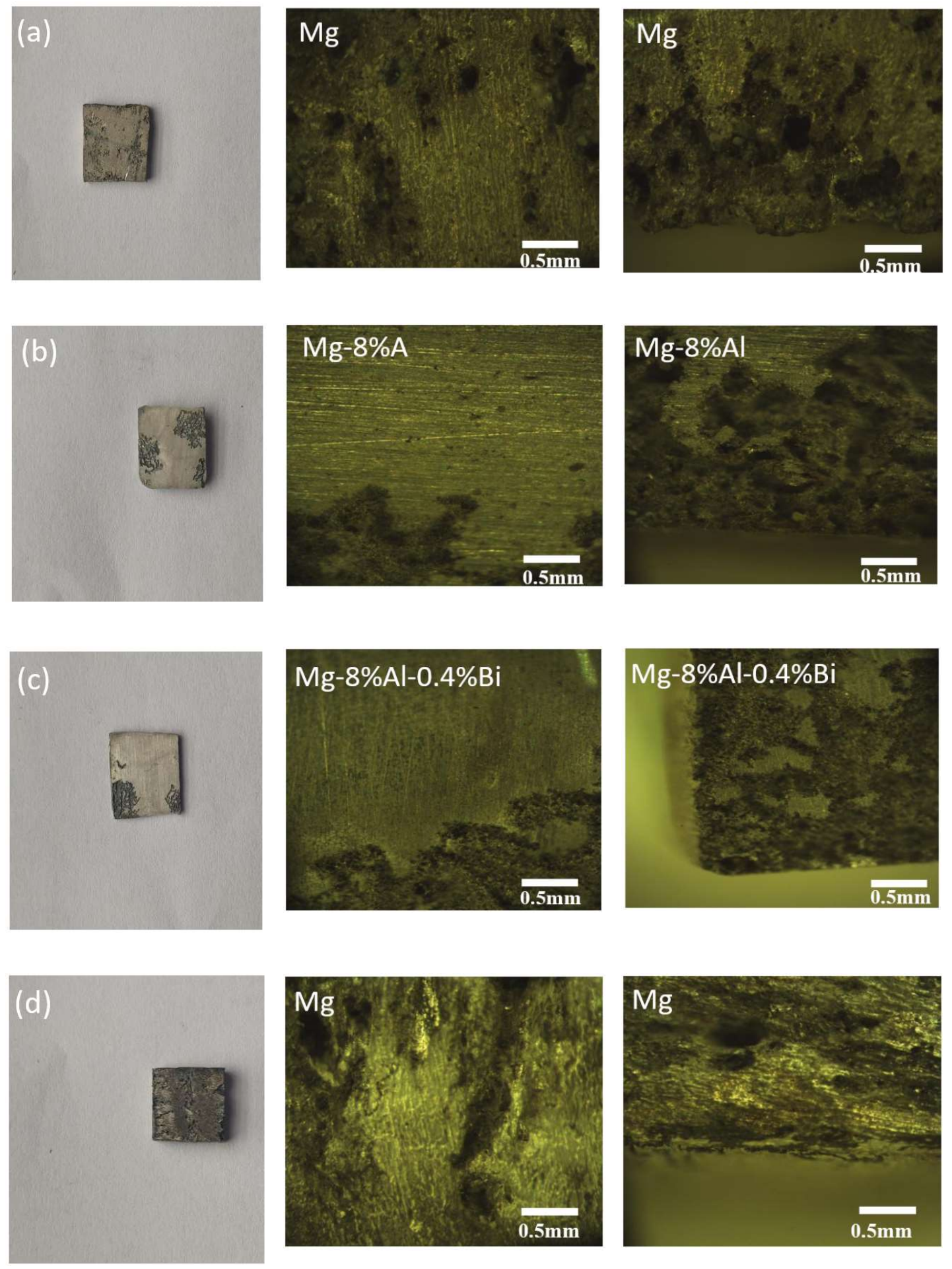

Figure 10. Cont. 

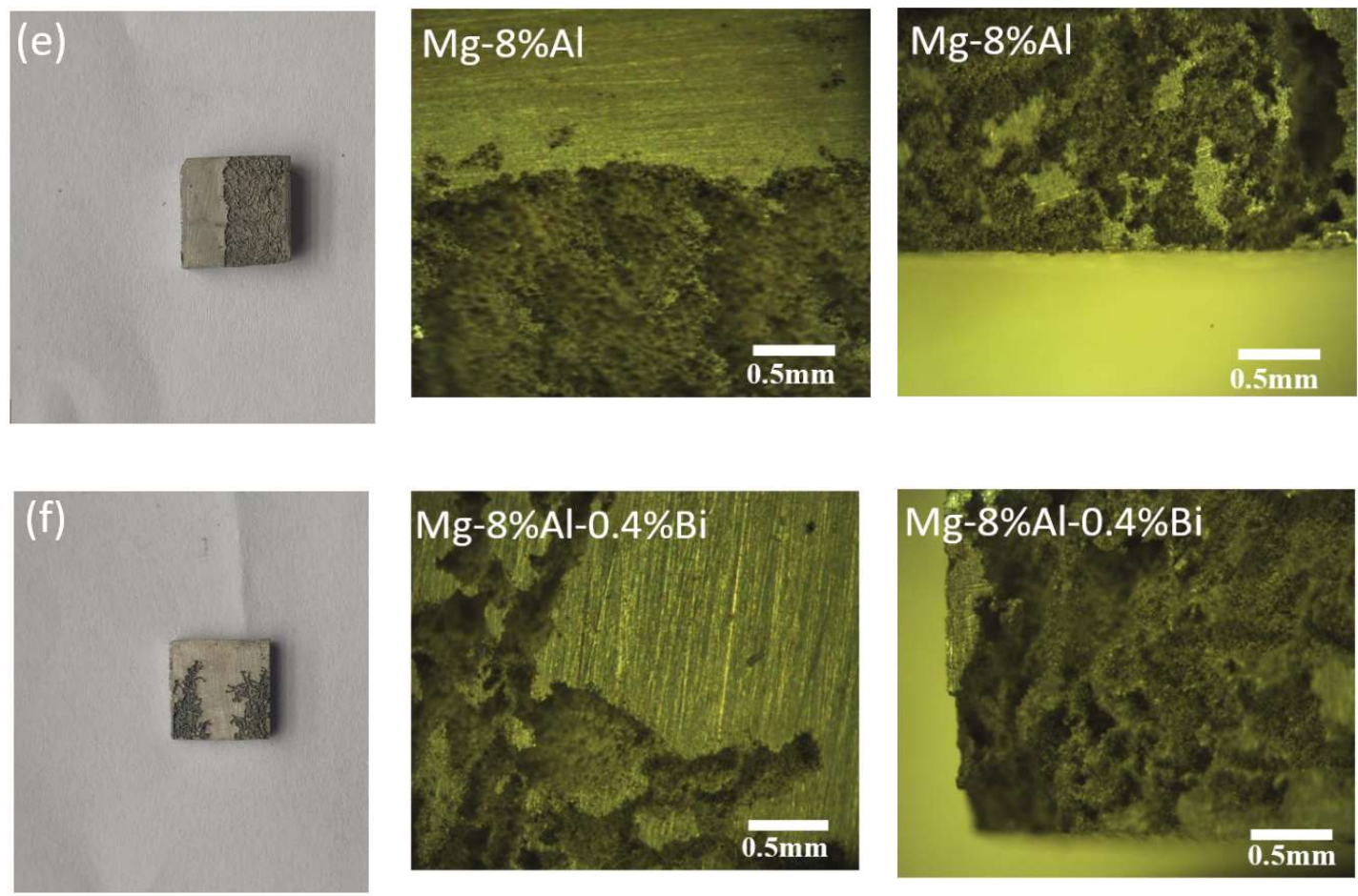

Figure 10. Metallographic microscope images of (a) $\mathrm{Mg}$,(b) $\mathrm{Mg}-8 \% \mathrm{Al}$, and (c) $\mathrm{Mg}-8 \% \mathrm{Al}-0.4 \% \mathrm{Bi}$ soaked in 3.5\% NaCl solution for $12 \mathrm{~h}$; (d) $\mathrm{Mg}$, (e) $\mathrm{Mg}-8 \% \mathrm{Al}$, and (f) $\mathrm{Mg}-8 \% \mathrm{Al}-0.4 \%$ Bi soaked in $3.5 \% \mathrm{NaCl}$ solution for $24 \mathrm{~h}$.

\section{Discussion}

The mechanism diagram of the pure $\mathrm{Mg}$ and $\mathrm{Mg}-8 \% \mathrm{Al}-0.4 \% \mathrm{Bi}$ alloy discharge process and the cross-section of corrosion products are depicted in Figure 11. Song [46] found that during the discharge process of magnesium and magnesium alloys, a protective film of $\mathrm{Mg}(\mathrm{OH})_{2}$ is formed on the anode surface. Because the protective layer is loose in the presence of certain ions (such as $\mathrm{Cl}$ - etc.) and cannot peel off quickly, the protective performance of the film is poor and the discharge performance is reduced, as shown in Figure 11a. However, it can be clearly seen from Figure 6 that the surface of the pure $\mathrm{Mg}$ is corroded very seriously after discharging in $120 \mathrm{~mA} \mathrm{~cm}^{-2}$, while the surface of the $\mathrm{Mg}-8 \% \mathrm{Al}-0.4 \% \mathrm{Bi}$ alloy is very flat and shows good corrosion resistance, which means the protection of the film formed by the $\mathrm{Mg}-\mathrm{Al}-\mathrm{Bi}$ alloy is greater than that of the $\mathrm{Mg}(\mathrm{OH})_{2}$ film formed by pure $\mathrm{Mg}$ in discharge. It can be seen from Figure 6 that after the addition of $\mathrm{Al}$ and $\mathrm{Bi}$, the corrosion resistance of the alloy becomes better and the alloy surface film becomes thin. This may be because Bi has a high hydrogen evolution overpotential. In general, the higher the hydrogen evolution overpotential, the greater the resistance of the hydrogen evolution reaction, thereby slowing down self-corrosion. At the same time, the $\mathrm{Mg}_{17} \mathrm{Al}_{12}$ and $\mathrm{BiOCl}$ produced in the discharge process peel off the $\mathrm{Mg}(\mathrm{OH})_{2}$ film, which improved the discharge performance of the anode, as shown in Figure 11b. 

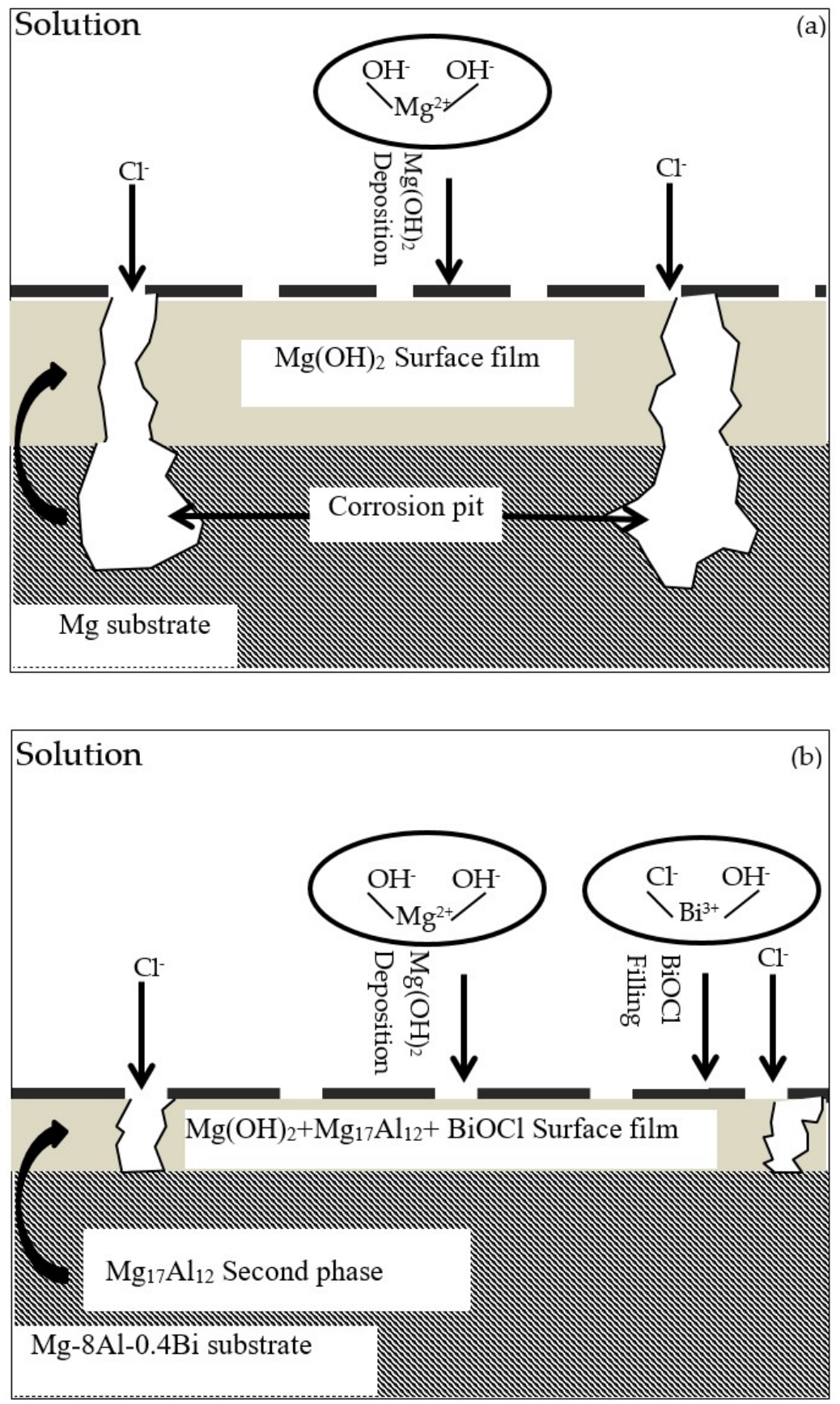

Figure 11. Discharge mechanism diagram of (a) $\mathrm{Mg}$ and (b) $\mathrm{Mg}-8 \% \mathrm{Al}-0.4 \% \mathrm{Bi}$ alloy for seawater battery anode.

\section{Conclusions}

1. The electrode performance of the as-cast $\mathrm{Mg}-8 \% \mathrm{Al}-0.4 \% \mathrm{Bi}$ alloy shows that compared with pure $\mathrm{Mg}$ or $\mathrm{Mg}-8 \% \mathrm{Al}$ alloy, it has a more negative discharge potential of $-1.185 \mathrm{~V}$ and a higher utilization rate of $72.4 \%$.

2. EIS research and immersion tests show that the chemical resistance of the Mg alloy surface protective film follows the following order: $\mathrm{Mg}<\mathrm{Mg}-8 \% \mathrm{Al}<\mathrm{Mg}-8 \% \mathrm{Al}-0.4 \% \mathrm{Bi}$. Therefore, the corrosion rate of the $\mathrm{Mg}-8 \% \mathrm{Al}-0.4 \% \mathrm{Bi}$ alloy in seawater is the slowest.

3. Different phases in the magnesium alloy play an important role in electrochemical performance. The $\mathrm{Mg}_{17} \mathrm{Al}_{12}$ and $\mathrm{BiOCl}$ phases in the as-cast $\mathrm{Mg}-8 \% \mathrm{Al}-0.4 \% \mathrm{Bi}$ alloy can increase the alloy utilization rate and promote the dissolution of $\alpha-\mathrm{Mg}$ in seawater during discharge. Moreover, 
the Bi element is environmentally friendly and pollution-free, which means that $\mathrm{Mg}-8 \% \mathrm{Al}-0.4 \% \mathrm{Bi}$ alloy is a promising electrode material for the anode of seawater-activated batteries.

Author Contributions: Data curation, X.M.; writing-review and editing, C.W. and W.W. All authors have read and agreed to the published version of the manuscript.

Funding: This research received no external funding.

Conflicts of Interest: The authors declare no conflict of interest.

\section{References}

1. Kerr, S.; Watts, L.; Colton, J.; Conway, F.; Hull, A.; Johnson, K.; Jude, S.; Kannen, A.; MacDougall, S.; McLachlan, C.; et al. Vergunst, Establishing an agenda for social studies research in marine renewable energy. Energy Policy 2014, 67, 694-702. [CrossRef]

2. Skjong, E.; Volden, R.; Rodskar, E.; Molinas, M.; Johansen, T.A.; Cunningham, J. Past, Present, and Future Challenges of the Marine Vessel's Electrical Power System. IEEE Trans. Transp. Electrif. 2016, 2, 522-537. [CrossRef]

3. Zhou, W.; Hao, F.; Fang, D. The effects of elastic stiffening on the evolution of the stress field within a spherical electrode particle of lithium-ion batteries. Int. J. Appl. Mech. 2013, 5, 1350040. [CrossRef]

4. Zhou, W. Effects of external mechanical loading on stress generation during lithiation in Li-ion battery electrodes. Electrochim. Acta 2015, 185, 28-33. [CrossRef]

5. Wen, L.; Yu, K.; Xiong, H.; Dai, Y.; Yang, S.; Qiao, X.; Teng, F.; Fan, S. Composition optimization and electrochemical properties of $\mathrm{Mg}-\mathrm{Al}-\mathrm{Pb}-\mathrm{Zn}$ alloys as anodes for seawater activated battery. Electrochim. Acta 2016, 194, 40-51. [CrossRef]

6. Wang, N.; Wang, R.; Peng, C.; Feng, Y.; Chen, B. Effect of hot rolling and subsequent annealing on electrochemical discharge behavior of AP65 magnesium alloy as anode for seawater activated battery. Corros. Sci. 2012, 64, 17-27. [CrossRef]

7. Yu, K.; Tan, X.; Hu, Y.; Chen, F.; Li, S. Microstructure effects on the electrochemical corrosion properties of $\mathrm{Mg}-4.1 \% \mathrm{Ga}-2.2 \% \mathrm{Hg}$ alloy as the anode for seawater-activated batteries. Corros. Sci. 2011, 53, 2035-2040. [CrossRef]

8. Wilcock, W.S.D.; Kauffman, P.C. Development of a seawater battery for deep-water applications. J. Power Sources 1977, 66, 71-75. [CrossRef]

9. Hasvold, Ø.; Størkersen, N. Electrochemical power sources for unmanned underwater vehicles used in deep sea survey operations. J. Power Sources 2001, 96, 252-258. [CrossRef]

10. Hwang, S.M.; Park, J.S.; Kim, Y.; Go, W.; Han, J.; Kim, Y.; Kim, Y. Rechargeable Seawater Batteries-From Concept to Applications. Adv. Mater. 2019, 31, 1804936. [CrossRef]

11. Shinohara, M.; Araki, E.; Mochizuki, M.; Kanazawa, T.; Suyehiro, K. Practical application of a sea-water battery in deep-sea basin and its performance. J. Power Sources 2009, 187, 253-260. [CrossRef]

12. Hasvold, Ø.; Lian, T.; Haakaas, E.; Størkersen, N.; Perelman, O.; Cordier, S. CLIPPER: A long-range, autonomous underwater vehicle using magnesium fuel and oxygen from the sea. J. Power Sources 2004, 136, 232-239. [CrossRef]

13. Feng, Y.; Wang, R.; Peng, C. Researches and applications of magnesium anode materials in seawater battery. Chin. J. Nonferrous Metals 2011, 21, 259-268.

14. Feng, Y.; Xiong, W.; Zhang, J.; Wang, R.; Wang, N. Electrochemical discharge performance of the $\mathrm{Mg}-\mathrm{Al}-\mathrm{Pb}-\mathrm{Ce}-\mathrm{Y}$ alloy as the anode for Mg-air batteries. J. Mater. Chem. 2016, 4, 8658-8668. [CrossRef]

15. Wang, N.; Li, W.; Huang, Y.; Wu, G.; Hu, M.; Li, G.; Shi, Z. Wrought Mg-Al-Pb-RE alloy strips as the anodes for Mg-air batteries. J. Power Sources 2019, 436, 226855. [CrossRef]

16. Wu, J.; Wang, R.; Feng, Y.; Peng, C. Effect of hot rolling on the microstructure and discharge properties of $\mathrm{Mg}-1.6 \mathrm{wt} \% \mathrm{Hg}-2 \mathrm{wt} \% \mathrm{Ga}$ alloy anodes. J. Alloys Compd. 2018, 765, 736-746. [CrossRef]

17. Wang, H.H.; Du, M.; Liang, H.; Gao, Q.Y. Study on Al-Zn-In Alloy as Sacrificial Anodes in Seawater Environment. J. Ocean Univ. 2019, 18, 889-895. [CrossRef]

18. Liu, X.; Xue, J.; Zhang, D. Electrochemical behaviors and discharge performance of the as-extruded Mg-1.5 ${ }_{w t} \%$ Ca alloys as anode for Mg-air battery. J. Alloys Compd. 2019, 790, 822-828. [CrossRef] 
19. Li, J.; Wan, K.; Jiang, Q.; Sun, H.; Li, Y.; Hou, B.; Zhu, L.; Liu, M. Corrosion and Discharge Behaviors of Mg-Al-Zn and Mg-Al-Zn-In Alloys as Anode Materials. Metals 2016, 6, 65. [CrossRef]

20. Wang, N.; Wang, R.; Peng, C.; Feng, Y.; Zhang, X. Influence of aluminium and lead on activation of magnesium as anode. Trans. Nonferrous Metals Soc. China 2010, 20, 1403-1411. [CrossRef]

21. Lin, M.; Uan, J. Preparation of bcc Mg-Li-Al-Zn Alloy by Electrolysis in Molten Salt LiCl-KCl and the Alloy's Electrochemical Performance as Anode Material for Magnesium Batteries. Electrochemistry 2009, 77, 604-607. [CrossRef]

22. Liu, X.; Liu, S.; Xue, J. Discharge performance of the magnesium anodes with different phase constitutions for Mg-air batteries. J. Power Sources 2018, 396, 667-674. [CrossRef]

23. Yu, Z.; Ju, D.; Zhao, H.; Hu, X. Effects of Zn-In-Sn elements on the electric properties of magnesium alloy anode materials. J. Environ. Sci. 2011, 23, S95-S99. [CrossRef]

24. Yin, M.; Hou, L.; Liu, X.; Wang, Z.; Liu, B.; Jia, J.; Zhang, S.; Wei, Y. Tailoring the micromorphology of the as-cast Mg-Sn-In alloys to corrosion-resistant microstructures via adjusting In concentration. J. Alloys Compd. 2019, 811, 152024. [CrossRef]

25. Baghni, I.M.; Wu, Y.S.; Li, J.Q.; Zhang, W. Corrosion behavior of magnesium and magnesium alloys. Trans. Nonferrous Metals Soc. China 2004, 14, 1-10.

26. Zhou, W.; Lin, J.; Dean, T.A.; Wang, L. Feasibility studies of a novel extrusion process for curved profiles: Experimentation and modelling. Int. J. Mach. Tools Manuf. 2018, 126, 27-43. [CrossRef]

27. Xiong, H.; Yu, K.; Yin, X.; Dai, Y.; Yan, Y.; Zhu, H. Effects of microstructure on the electrochemical discharge behavior of Mg-6wt\%Al-1wt\%Sn alloy as anode for Mg-air primary battery. J. Alloys Compd. 2004, 708, 652-661. [CrossRef]

28. Malyi, O.I.; Tan, T.L.; Manzhos, S. In search of high performance anode materials for Mg batteries: Computational studies of Mg in Ge, Si, and Sn. J. Power Sources 2013, 233, 341-345. [CrossRef]

29. Yuasa, M.; Huang, X.; Suzuki, K.; Mabuchi, M.; Chino, Y. Discharge properties of Mg-Al-Mn-Ca and Mg-Al-Mn alloys as anode materials for primary magnesium-air batteries. J. Power Sources 2015, 297, 449-456. [CrossRef]

30. Deng, M.; Höche, D.; Lamaka, S.V.; Wang, L.; Zheludkevich, M.L. Revealing the impact of second phase morphology on discharge properties of binary Mg-Ca anodes for primary Mg-air batteries. Corros. Sci. 2019, 153, 225-235. [CrossRef]

31. Balasubramanian, R.; Veluchamy, A.; Venkatakrishnan, N.; Gangadharan, R. Electrochemical characterization of magnesium/silver chloride battery. J. Power Sources 1995, 56, 197-199. [CrossRef]

32. Ma, J.; Wang, G.; Li, Y.; Qin, C.; Ren, F. Electrochemical Investigations on AZ Series Magnesium Alloys as Anode Materials in a Sodium Chloride Solution. J. Mater. Eng. Perform. 2019, 28, 2873-2880. [CrossRef]

33. Wang, N.; Wang, R.; Peng, C.; Feng, Y. Enhancement of the discharge performance of AP65 magnesium alloy anodes by hot extrusion. Corros. Sci. 2014, 81, 85-95. [CrossRef]

34. Feng, Y.; Wang, R.; Yu, K.; Peng, C.; Zhang, J.; Zhang, C. Activation of Mg-Hg anodes by Ga in $\mathrm{NaCl}$ solution. J. Alloys Compd. 2009, 473, 215-219. [CrossRef]

35. Feng, Y.; Wang, R.; Yu, K.; Peng, C.; Li, W. Influence of Ga and Hg on microstructure and electrochemical corrosion behavior of Mg alloy anode materials. Trans. Nonferrous Metals Soc. China 2009, 17, 1363-1366. [CrossRef]

36. Feng, Y.; Wang, R.; Peng, C. Influence of aging treatments on microstructure and electrochemical properties in $\mathrm{Mg}-8.8 \mathrm{Hg}-8 \mathrm{Ga}(\mathrm{wt} \%)$ alloy. Intermetallics $2013,33,120-125$.

37. Liu, R.L.; Scully, J.R.; Williams, G.; Birbilis, N. Reducing the corrosion rate of magnesium via microalloying additions of group 14 and 15 elements. Electrochim. Acta 2018, 260, 184-195. [CrossRef]

38. Xiong, H.; Zhu, H.; Luo, J.; Yu, K.; Shi, C.; Fang, H.; Zhang, Y. Effects of Heat Treatment on the Discharge Behavior of Mg-6wt.\%Al-1wt.\%Sn Alloy as Anode For Magnesium-Air Batteries. J. Mater. Eng. Perform. 2017, 26, 2901-2911. [CrossRef]

39. Zhao, M.-C.; Schmutz, P.; Brunner, S.; Liu, M.; Song, G.-1.; Atrens, A. An exploratory study of the corrosion of $\mathrm{Mg}$ alloys during interrupted salt spray testing. Corros. Sci. 2009, 51, 1277-1292. [CrossRef]

40. Song, G.; Atrens, A.; Dargusch, M. Influence of microstructure on the corrosion of diecast AZ91D. Corros. Sci. 1998, 41, 249-273. [CrossRef]

41. Chen, F.; Leong, Z.Y.; Yang, H.Y. An aqueous rechargeable chloride ion battery. Energy Storage Mater. 2017, 7, 189-194. [CrossRef] 
42. Cao, D.; Wu, L.; Wang, G.; Lv, Y. Electrochemical oxidation behavior of Mg-Li-Al-Ce-Zn and $\mathrm{Mg}-\mathrm{Li}-\mathrm{Al}-\mathrm{Ce}-\mathrm{Zn}-\mathrm{Mn}$ in sodium chloride solution. J. Power Sources 2008, 183, 799-804. [CrossRef]

43. Wang, N.; Wang, R.; Peng, C.; Peng, B.; Feng, Y.; Hu, C. Discharge behaviour of Mg-Al-Pb and Mg-Al-Pb-In alloys as anodes for Mg-air battery. Electrochim. Acta 2014, 149, 193-205. [CrossRef]

44. Andrei, M.; di Gabriele, F.; Bonora, P.L.; Scantlebury, D. Corrosion behaviour of magnesium sacrificial anodes in tap water. Mater. Corros. 2003, 54, 5-11. [CrossRef]

45. Ramirez, O.M.P.; Queiroz, F.M.; Tunes, M.A.; Antunes, R.A.; Rodrigues, C.L.; Lanzutti, A.; Pogatscher, S.; Olivier, M.-G.; de Melo, H.G. Tartaric-sulphuric acid anodized clad AA2024-T3 post-treated in Ce-containing solutions at different temperatures: Corrosion behaviour and Ce ions distribution. Appl. Surf. Sci. 2020, 534, 147634. [CrossRef]

46. Song, G.L.; Unocic, K.A. The anodic surface film and hydrogen evolution on Mg. Corros. Sci. 2015, 98, 758-765. [CrossRef]

Publisher's Note: MDPI stays neutral with regard to jurisdictional claims in published maps and institutional affiliations.

(C) 2020 by the authors. Licensee MDPI, Basel, Switzerland. This article is an open access article distributed under the terms and conditions of the Creative Commons Attribution (CC BY) license (http://creativecommons.org/licenses/by/4.0/). 